\title{
PURPOSE-BASED GOVERNANCE: A NEW PARADIGM
}

\author{
ROSEMARY TEELE LANGFORD*
}

\begin{abstract}
The permissibility of corporations pursuing purposes other than profit has been the subject of debate for a number of years. This debate has intensified recently with proposals to allow or mandate the adoption of purposes by corporations. At the same time, purpose is central to governance in the charitable sphere. This article proposes a model of 'purpose-based governance', which offers significant potential advantages in both the charitable and for-profit spheres, as well as forming the basis of a unifying governance paradigm.
\end{abstract}

\section{INTRODUCTION}

Trust in societal institutions has decreased progressively in the last two decades, ${ }^{1}$ with two recent royal commissions highlighting the need for improved governance in both the charitable and corporate spheres. ${ }^{2}$ A governance model centred on purpose - referred to in this article as 'purpose-based governance' offers potential for refocusing and reinvigorating governance. This model works particularly well in relation to charitable entities given that charities are required to articulate their purposes and given the importance of purpose in maintaining charitable status and registration. The importance of purpose is also increasingly recognised in the corporate sphere. Indeed, a revolutionary transformation of corporate governance and regulation based on purpose has been proposed by Mayer and the British Academy. ${ }^{3}$ Media attention has recently surrounded the Business Roundtable's release of a new statement on the purpose of corporations

* Associate Professor, Melbourne Law School, University of Melbourne. This research was funded by the Australian Government through the Australian Research Council. My thanks to the many people I consulted on this topic, to Miranda Webster for research assistance and to the anonymous referees for their valuable comments.

1 See Edelman Intelligence, ‘2019 Edelman Trust Barometer: Executive Summary’ (Survey, 2019) 2. See also Simon Longstaff and Victoria Whitaker, 'Trust, Legitimacy \& the Ethical Foundations of the Market Economy' (The Ethics Centre, August 2018) 3-4.

2 Royal Commission into Institutional Responses to Child Sex Abuse (Final Report, December 2017) preface and executive summary, 56; Royal Commission into Misconduct in the Banking, Superannuation and Financial Services Industry (Final Report, February 2019) vol 1, 15-16 ('Banking Royal Commission Report').

3 Colin Mayer, 'Reinventing the Corporation' (2016) 4 Journal of the British Academy 53; The British Academy, Reforming Business for the $21^{\text {st }}$ Century: A Framework for the Future of the Corporation (Report, 2018) ('Reforming Business for the $21^{\text {st }}$ Century'). 
which outlines a 'fundamental commitment to all ... stakeholders' ${ }^{4}$ In addition, there is increased demand for business models that incorporate more than the generation of profit. Examples are shared value ${ }^{5}$ and social enterprise models. ${ }^{6}$

At its core the purpose-based governance model outlined in this article sees purpose as central to governance, with other governance duties emanating from clearly defined purpose. Purpose forms the underlying governance requirement with other duties supporting it. This is built on purpose-based loyalty - on governance driven by fidelity to purpose. Purpose-based governance sits within fiduciary theory, without the need for revolutionary change. At the same time, however, it supports broader theoretical proposals for purpose as the overarching fiduciary paradigm.

The key role of purpose in the charitable sphere demonstrates the way in which purpose could play a role in the corporate sphere. Articulation of purpose(s) in company constitutions would provide a gateway for purpose to take on a significant role in governance. This could, in particular, help solve the conundrum as to the extent to which directors can consider and promote the interests of stakeholders in properly carrying out their duties. At the very least purpose could play a motivating, connecting and signalling role in the corporate sphere.

This article outlines and critically assesses the advantages of a purpose-based governance model. The focus is on re-centering governance without necessarily implementing significant legal change, although the potential for such change is considered at various points. It is demonstrated that a purpose-based governance model has its most cogent application in the charitable sphere but has clear potential across a spectrum of different entities. This article does not specifically consider purpose-based governance in the context of not-for-profit entities that are not charities. Many such entities do, however, articulate purposes and purposebased governance is therefore apposite in relation to such entities.

\section{WHAT IS PURPOSE-BASED GOVERNANCE?}

Governance can be defined as the framework of rules, relationships, systems and processes within which, and by which, authority is exercised and controlled within entities. It encompasses the mechanisms by which entities, and those in control, are held to account. ${ }^{7}$

4 'Statement on the Purpose of a Corporation', Business Roundtable (Web Page, 19 August 2019) $<$ https://opportunity.businessroundtable.org/ourcommitment/>.

5 See Michael E Porter and Mark R Kramer, 'Creating Shared Value: How to Reinvent Capitalism - And Unleash a Wave of Innovation and Growth’ [2011] (January-February) Harvard Business Review 62.

6 For definition, see Commonwealth of Australia, Strengthening for Purpose: Australian Charities and Not-For-Profits Commission Legislation Review 2018 (Report, 31 May 2018) 17.

7 Adapted from Royal Commission into HIH Insurance (Report, April 2003) vol 1, xxxiii, as quoted in ASX Corporate Governance Council, 'Corporate Governance Principles and Recommendations' $\left(4^{\text {th }} \mathrm{ed}\right.$, February 2019) 1. 
This article proposes a new model of governance - purpose-based governance. This model is a system of governance centred around obligations connected with purpose-based loyalty - a model of fidelity to purpose. Core governance duties are connected to, and therefore informed and shaped by, the entity's purposes. In other words, rather than a series of separate duties aimed at ensuring high standards of conduct (or at ensuring that those who govern entities act in the interests of the entity), the duties emanate from, and support, the furtherance of an entity's purposes. In this way the practical content and application of the core governance duties of those who govern entities (referred to in this article as 'responsible persons') are closely connected with the entity's purpose.

The impact of purpose-based governance is necessarily greater in the charitable context because charitable entities are required to specify their purpose(s) and because of the financial incentives and regulatory regime which incentivise charities to adhere to purpose in order to maintain charitable status and registration (and associated tax benefits). ${ }^{8}$ The requirement for clear expression of purpose in the charitable sphere provides a model which could be adopted in the corporate sphere. The key difference between the charitable and for-profit spheres is the fact that charities are required to articulate, and stay true to, their charitable purpose(s).

Purpose-based governance draws on the fiduciary model. ${ }^{9}$ It does so in two ways. First, the interests of a person or entity arguably cannot be determined without reference to the purposes of the arrangement in which those interests fall to be considered. As stated by Lord Nicholls of Birkenhead (in the context of trustees' duties):

To decide whether a proposed course is for the benefit of the beneficiaries or is in their best interests, it is necessary to decide first what is the purpose of the trust and what benefits were intended to be received by the beneficiaries. Thus, to define the trustee's obligation in terms of acting in the best interests of the beneficiaries is to do nothing more than formulate, in different words, a trustee's obligation to promote the purpose for which the trust was created. ${ }^{10}$

Secondly, fidelity to purpose has the potential to bring a new unity to fiduciary law. The accepted paradigm that fiduciaries must subordinate their self-interest to the interests of the beneficiary is a subset of a wider paradigm requiring fiduciaries to subordinate their self-interest to purpose. Fox-Decent writes that 'the most fundamental and general fiduciary duty is not loyalty to an individual or a discrete

8 See, eg, Australian Charities and Not-For-Profits Commission Regulation 2013 (Cth) reg 45.5(2) ('ACNC Regulation').

9 The foundation on which governance of charitable and corporate entities is based is the fiduciary paradigm. Regulation 45.25(1) of the ACNC Regulation states:

The object of this governance standard is (1) to ensure that the responsible entities of a registered entity conduct themselves in the manner that would be necessary if: (i) the relationship between them and the entity were a fiduciary relationship; and (ii) they were obliged to satisfy minimum standards of behaviour consistent with that relationship.

10 Lord Nicholls of Birkenhead, 'Trustees and Their Broader Community: Where Duty, Morality and Ethics Converge' (1996) 70(3) Australian Law Journal 205, 211. For discussion of the role of purposes in trusts law, see Matthew Harding, 'Equity and Institutions' in Dennis Klimchuk, Irit Samet and Henry E Smith (eds), Philosophical Foundations of the Law of Equity (Oxford University Press, 2020) 333. 
class of beneficiaries, but fidelity to the other-regarding purposes for which the fiduciary power is held'. 11

At the very least, fidelity to purposes is a second strand of the fiduciary paradigm. For example, Miller and Gold outline a governance mandate model as an alternative to a model based on a service mandate. ${ }^{12}$ Under this governance mandate fiduciaries exercise discretionary power to promote particular purposes. The relevant duties may or may not be owed to particular beneficiaries. Miller and Gold develop a model of fiduciary loyalty to purposes under which the fiduciary is loyal to an entity or beneficiary by allegiance to certain purposes. This loyalty is generally demonstrated by the fiduciary exercising their discretionary powers exclusively with a mind to advancing those purposes.

It can be seen that there is divergence of opinion as to whether a purpose-based fiduciary model is separate to a model focused on the interests of beneficiaries (as propounded by Miller and Gold) or whether the latter is an aspect of the former (as propounded by Fox-Decent). In a sense all governance is purpose-based in that governance framed around the best interests of a person or entity has the purpose of benefiting that person or entity and is therefore a subset of purposes. However, on either view, the fiduciary basis of the governance model remains intact, if not strengthened.

\section{POTENTIAL ADVANTAGES OF A PURPOSE-BASED MODEL}

The purpose-based governance model, as outlined and explained in more detail in the next Parts, has a number of potential advantages.

First, a purpose-based governance model has the potential to apply across the board to different forms and categories of entity and association ranging from charitable entities to for-profit companies. This has the associated advantage of simplicity.

Secondly, purpose-based governance facilitates a different way of framing questions and responding to the exercise of authority. It presents a new lens through which to approach persistent governance problems. In particular, purpose can shape our interpretation of what a person or entity's interests are. Indeed, purpose is arguably fundamental to an assessment of best interests. This is particularly useful in relation to artificial persons such as corporations. Purpose

11 Evan Fox-Decent, 'The Nature of State Legal Authority' (2005) 31(1) Queen's Law Journal 259, 268. He also writes that 'in its most fundamental and general form, the fiduciary obligation is an obligation to exercise fiduciary power exclusively for the sake of the other-regarding purposes for which it is held or conferred ... [the] best interests and conflicts duties are] sub-species of [the] more general fiduciary obligation': at 261. See also Paul B Miller, 'Corporations' in Andrew S Gold et al (eds), The Oxford Handbook of the New Private Law (Oxford University Press, forthcoming).

12 Paul B Miller and Andrew S Gold, 'Fiduciary Governance' (2015) 57(2) William and Mary Law Review 513, 561-3. See also Andrew S Gold and Paul B Miller, 'Fiduciary Duties in Social Enterprise' in Benjamin Means and Joseph W Yockey (eds), The Cambridge Handbook of Social Enterprise Law (Cambridge University Press, 2018) 321. 
justifies a longer-term approach to decision-making in the sense that an entity's purpose endures beyond the members and the entity in some cases.

A particular governance problem that purpose-based governance can assist in solving is issues relating to stakeholder demands - a purpose-based model presents an alternative to distributive justice. Rather than necessarily always providing a definitive answer to these tensions, purpose-based governance provides a new perspective from which decision-making can be approached - it elevates the focus above a lower level examination of, and mediation between, different competing interests. For example, responsible persons of a charity whose purposes include supporting disabled people may take the view that in order to fulfil the charity's purpose they also need to consider and cater for the needs of the families of people with a disability. Providing benefits to families would not constitute promotion of the interests of unconnected stakeholders, and therefore would not be inconsistent with acting in the interests of the charitable entity because this would be connected with, and therefore support, the entity's purpose. Judd, Robinson and Errington give the example of a charity whose purpose is to do something for the aged homeless and therefore provides housing and care to elderly, frail homeless men and women but does not provide housing for wealthy older people or services for the younger homeless. ${ }^{13}$

The purpose of the charity is therefore instrumental in responding to competing stakeholder demands. Likewise, as illustrated in Part V(B) below, the directors of a for-profit company whose purposes include benefiting a number of stakeholders would arguably have more leeway in benefiting such stakeholders than those of a company whose purpose was focused on returns to shareholders.

Thirdly, at the very least, purpose-based governance sets the boundaries around governance. Articulating purpose as the focus of governance signals what responsible persons cannot do. For example, responsible persons are commonly subject to a duty to act for proper purposes - acting for improper purposes constitutes a breach of duty. ${ }^{14}$ As outlined in Part IV(B)(1) below, purpose-based governance adds an additional dimension to this duty.

Fourthly, purpose-based governance provides an alternative explanation for, and therefore makes further sense of, other governance rules such as those relating to conflicts and profits. These rules keep responsible persons focused on the purpose of the entity - the rules function to dissuade people from being tempted away from focusing on, and seeking to achieve, those purposes. As with the proper purposes duty, purpose adds an extra aspect to these rules. ${ }^{15}$

Fifthly, a focus on purpose has organisational and motivational advantages. Organising governance and compliance around purpose makes sense of, and detangles, complex governance and compliance requirements. It also explains the need for attention to governance and compliance, thus providing motivation for such attention. In the charitable sphere the fact that compliance with regulatory requirements is vital to maintaining charitable registration and tax benefits (and

13 Stephen Judd, Anne Robinson and Felicity Errington, Driven by Purpose: Charities That Make the Difference (Hammond Press, 2012) 136.

14 See further below Part IV(B)(1).

15 See below Part IV(B)(3). 
thus to being able to pursue the charity's purpose effectively) ${ }^{16}$ helps explain the importance of compliance and thus motivate compliance. In addition, good governance advances an entity's purpose.

Sixthly, purpose sets the foundation for a determination and outworking of an entity's values and culture. This can be seen in Principle B of the UK Corporate Governance Code, which states: 'The board should establish the company's purposes, values and strategy, and satisfy itself that these and its culture are aligned'. ${ }^{17}$ Purpose also features in the commentary to the ASX Corporate Governance Principles and Recommendations. ${ }^{18}$

Purpose-based governance is also a means of adopting and legitimating ethical and ideological decision-making. This can be illustrated by the following example involving two entities that are considering tendering for commercial contracts with an energy company. The first entity is a charitable company whose purposes include advancing the natural environment. The second is a for-profit company (with shareholders) without specified purposes. The conditions of the tender proscribe successful tenderers receiving funding from, or donating to, any organisations that actively promote action on climate change. This troubles the directors of both entities. The directors of the first entity (whose charitable purposes include advancing the natural environment) have firm ground on which to decline to submit a tender for the work because it is inconsistent with the entity's purposes. The directors of the second entity arguably have less leeway unless they consider that putting in the tender would not be in the company's interests (for example due to its reputation). This distinction should not, however, be overstated due to the fact that for-profit companies are increasingly needing to take account of such issues in acting in good faith in the interests of the company. In addition, the directors of each entity would need to be mindful of their duty of care, skill and diligence in assessing the merits of this course of action.

Finally, a purpose-based governance model helps us understand what law and regulation could look like in empowering responsible persons to focus on purpose or requiring entities to clearly set out purposes.

It might be thought that purpose-based governance creates a risk of potential decreased accountability of responsible persons. However, the purpose-based governance model advocated in this article does not propose altering current accountability frameworks. In addition, as outlined in Part V below, this risk can be countered by clear drafting of constitutional objects. ${ }^{19}$

In summary, a focus on purpose opens up new ways of thinking and approaching problems and tensions that responsible persons commonly face. It helps with internal and external challenges such as the goals an entity pursues, the

16 See, eg, Australian Charities and Not-For-Profits Commission Act 2012 (Cth) s 45-5(2).

17 Financial Reporting Council, 'The UK Corporate Governance Code' (Code, July 2018) 4. Provision 2 states: 'The board should assess and monitor culture. Where it is not satisfied that policy, practices or behaviour throughout the business are aligned with the company's purposes, values and strategy, it should seek assurance that management has taken corrective action': at 4.

18 'Corporate Governance Principles and Recommendations' (n 7) 3, 16, 31.

19 For more detail, see below Part V(B). 
way that the entity handles stakeholders, the way that decision-making is framed and constrained and the determination of values and culture. More broadly, it assists in shaping and forming a basis for culture within entities and in determining what form applicable law and regulation should take.

\section{CHARITIES}

The focus of this Part of the article is on charitable entities (rather than all notfor-profit entities). The term 'charitable entity' encompasses the spectrum of different types of charitable entity which are registered and gain tax advantages from such registration. This includes trusts, companies, incorporated associations, unincorporated associations, statutory bodies and co-operatives.

\section{A Charities and the Importance of Purpose}

Purpose is at the core of charitable entities - it determines charitable status and registration, as well as tax exemptions. A charity that strays from its purpose may be the subject of investigation by the Australian Charities and Not-for-profits Commission. ${ }^{20} \mathrm{~A}$ charity's purpose and activities connected with its purpose also partly determine which laws, codes and regulations the charity must comply with. ${ }^{21}$ The importance of purpose is underscored by the case of Federal Commissioner of Taxation v Word Investments Ltd ('Word Investments') in which the High Court placed significant weight on the purpose of the charity rather than its activities in determining whether an entity was a tax-exempt charity. ${ }^{22}$

Purpose is also one of the key reasons why we value charities. A charity's purpose encourages vision, commitment and volunteering. It motivates employees, drives performance and operates as a reference point and safety mechanism. In the words of Judd, Robinson and Errington:

Being purpose-driven affects the entire character and operation of a charity. It affects its direction and its strategies. It affects what the board and management are focussed on and even who is on the board. It impacts on the level of employee engagement, on staff recruitment and remuneration and performance appraisal. Being purpose-driven affects how a charity is engaged with its community and how it approaches its finances. ${ }^{23}$

Likewise, the Australian Institute of Company Directors' Not-For-Profit Governance Principles state:

An organisation's purpose is what it hopes to achieve. It is the reason the organisation exists, and all its activities should contribute to achieving its purpose

20 See 'What the ACNC Can Investigate', Australian Charities and Not-for-profits Commission (Web Page) $<$ https://www.acnc.gov.au/raise-concern/concerns-about-charities/what-acnc-can-investigate $>$.

21 For example, charities whose purposes are to advance health must comply with relevant health sector laws and regulations; charities that operate outside Australia are required to comply with the ACNC External Conduct Standards: see 'ACNC External Conduct Standards', Australian Charities and Not-forprofits Commission (Web Page) <acnc.gov.au/externalconductstandards>.

22 (2008) 236 CLR 204, 214-26 (Gummow, Heydon, Hayne and Crennan JJ) ('Word Investments').

23 Judd, Robinson and Errington (n 13) 14. 
in some way. It is the 'what' and the 'why' of an organisation's work. Purpose is the centrepiece of governance in the NFP sector. ${ }^{24}$

The Productivity Commission observed that '[v]olunteers who understand and believe in the mission of an organisation are more likely to continue volunteering, 25

The importance of purpose is underscored by regulation 45.5(2) of the Australian Charities and Not-For-Profits Commission Regulation 2013 (Cth) ('ACNC Regulation'), which states:

A registered entity must: (a) be able to demonstrate, by reference to the governing rules of the entity or by other means, its purposes and its character as a not-forprofit entity; and (b) make information about its purposes available to the public, including members, donors, employees, volunteers and benefit recipients; and (c) comply with its purposes and its character as a not-for-profit entity. ${ }^{26}$

There is also an essential connection between purpose and governance in this sphere, as is now outlined. ${ }^{27}$

\section{B Charities and Purpose-Based Governance}

Purpose-based governance sees an entity's purpose as central to the governance duties of responsible persons - purpose is the guiding governance requirement with the other requirements supporting this. The core duty of responsible persons is to act in good faith in what they consider will further the charity's purposes.

This Part of the article uses the ACNC Governance Standards in regulation 45.25 of the $A C N C$ Regulation to demonstrate how purpose-based governance is worked out in the charitable sphere. There are, of course, numerous different sources and expressions of governance duties that apply to charitable entities, arising from the general law and a number of statutes. It is important for responsible persons to comply with these other duties rather than solely focusing on the Governance Standards alone. The Governance Standards apply to all registered charitable entities and will therefore be referred to for the purposes of analysis. The aim of this Part of the article is not to outline and critically analyse all aspects of each duty but, rather, to demonstrate how purpose shapes each of the duties.

Governance Standard 5, contained in regulation 45.25(2), which sets out the duties of responsible persons, provides:

24 Australian Institute of Company Directors, 'Not-For-Profit Governance Principles' (Principles, $2^{\text {nd }}$ ed, January 2019) 22. See also Principle 1 , which states that '[t] he organisation has a clear purpose and a strategy which aligns its activities to its purpose': at 4.

25 Productivity Commission, Contribution of the Not-For-Profit Sector (Research Report, January 2010) 250 .

26 The impact of purpose is also evident when charitable entities are wound up in that the assets are often distributed to entities with similar purposes: for detail, see GE Dal Pont, Law of Charity (LexisNexis Butterworths, $\left.2^{\text {nd }} \mathrm{ed}, 2017\right) \mathrm{ch} 15$.

27 See also Australian Government, Australian Charities and Not-for-profits Commission, 'Managing Conflicts of Interest: A Guide for Charity Board Members' (Guide, November 2015) 5 ('Managing Conflicts of Interest'). 
(2) A registered entity must take reasonable steps to ensure that its responsible entities are subject to, and comply with, the following duties:

(a) to exercise the responsible entity's powers and discharge the responsible entity's duties with the degree of care and diligence that a reasonable individual would exercise if they were a responsible entity of the registered entity;

(b) to act in good faith in the registered entity's best interests, and to further the purposes of the registered entity;

(c) not to misuse the responsible entity's position;

(d) not to misuse information obtained in the performance of the responsible entity's duties as a responsible entity of the registered entity;

(e) to disclose perceived or actual material conflicts of interest of the responsible entity;

(f) to ensure that the registered entity's financial affairs are managed in a responsible manner;

(g) not to allow the registered entity to operate while insolvent. ${ }^{28}$

\section{Best Interests and Proper Purposes}

The core duty of responsible persons is expressed in regulation 45.25(2)(b) of the $A C N C$ Regulation, which requires responsible persons 'to act in good faith in the registered entity's best interests, and to further the purposes of the registered entity'. The first part of this duty parallels the core duty of directors of all companies to act in good faith in the interests of the company ${ }^{29}$ and the irreducible core duty of trustees to 'perform the [trust] honestly and in good faith for the benefit of the beneficiaries'. 30

A key question is therefore what the interests of the charitable entity are. For charitable entities these are tied up with the entity's purposes. The best interests of the entity are the fulfilment of its purposes. Contrary to the phrasing of regulation 45.25(2)(b) of the ACNC Regulation, the interests of the entity are not separate to the furtherance of its purposes. Rather the two are intertwined. This duty could be reformulated as a duty to act in good faith in the interests of the charity's purposes or a duty to exercise powers in good faith in the way the responsible person considers would further the charity's purposes. ${ }^{31}$ This is reflected in the recent judgment in Australian Prudential Regulation Authority v Kelaher in which Jagot J said: 'acting in the best interest of the beneficiaries is in effect synonymous with

28 Section 205-30 of the Australian Charities and Not-For-Profits Commission Act 2012 (Cth) defines responsible entities to include directors, trustees and other persons involved in a charity's governing body.

29 See, eg, Re Smith and Fawcett Ltd [1942] Ch 304, 306 (Lord Greene); Australian Securities and Investments Commission v Lewski (2018) 362 ALR 286, 304 [71] (Kiefel CJ, Bell, Gageler, Keane and Edelman JJ) ('Lewski').

30 Armitage v Nurse [1998] Ch 241, 253 (Millett LJ).

31 In the recent UK Court of Appeal decision in Children's Investment Foundation Fund (UK) v Attorney General [2019] Ch 139, 160 [48], the Court found that members had a duty when exercising shareholder powers to further the purposes of the charity, stating: '[T] he member must exercise the powers that he has in that capacity in the way that he decides, in good faith, would be most likely to further the purposes of the [charity in question]' (emphasis omitted). 
a trustee's obligation to promote and act consistently with the purpose for which the trust was established .... 32

The importance of purpose in the application of this duty can be illustrated in the context of decisions made in relation to mergers. For example, a board may decide that the best way to achieve an entity's purpose is for the entity to cease to exist and to transfer its assets (and liabilities) to another entity with a similar purpose which is better placed to achieve the purpose. On the other hand, a board may decide that, despite dwindling member numbers and the financial incentives to merge, the purposes of the entity are best fulfilled by not merging. This can be illustrated in the following example. Say two bodies promoting women's football are established as separate entities in neighbouring (but large) country districts of District A and District B. The purpose of the entity in District A (Entity A) is to promote women's football in District A and the purpose of the entity in District B (Entity B) is to promote women's football in District B. Entity A is struggling with dwindling membership and low community interest but is not yet in danger of insolvent trading. The governing body of Entity A has reasonable grounds to believe that this will change and that more people will join the entity and respond to its programs in due course. Entity B, although not thriving, is financially stable with decent membership numbers and moderate community interest in its programs. The governing body of Entity B suggests to the governing body of Entity A that the two entities should merge, close down Entity A's facilities and meet at Entity B's property. Faced with this decision, the governing body of Entity A would arguably be justified in giving weight to Entity A's purpose, namely to promote women's football in District A and in therefore not necessarily acceding to the merger (subject to duties of care and avoiding insolvent trading).

Purpose also justifies a longer term view to decision-making in the sense that an entity's purpose endures beyond the members and the entity in some cases this would assist in situations such as those involved in Grain Technology Australia Ltd v Rosewood Research Pty Ltd ('Bread Institute Case') in that the purpose of an entity survives beyond the members and even the winding up of an entity. ${ }^{33}$

The duty requires good faith consideration of the entity's purposes and action directed at furthering those purposes. It is not an absolute duty to achieve these purposes - the duty is not breached if these purposes are not achieved. ${ }^{34}$ As articulated by the High Court in Australian Securities and Investments Commission v Lewski ('Lewski') (in the context of a managed investment scheme):

Although the duty is not satisfied merely by honesty, it is a duty to act in the best interests of the members rather than a duty to secure the best outcome for members. Key factors in ascertaining the best interests of the members are the purpose and

32 [2019] FCA 1521, [65].

33 [2019] NSWSC 1111.

34 See Lewski (2018) 362 ALR 286, 304 [71] (Kiefel CJ, Bell, Gageler, Keane and Edelman JJ); Rosemary Teele Langford, Company Directors' Duties and Conflicts of Interest (Oxford University Press, 2019) 18, 332. 
terms of the scheme, rather than 'the success or otherwise of a transaction or other course of action'. ${ }^{35}$

The Governance Standards do not specifically mention the duty to act for proper purposes, instead referring to furthering the purposes of the registered entity. The proper purposes rule at general law requires directors to act for proper purposes, so that they are in breach if they act for purposes other than a proper purpose. $^{36}$ This means that responsible persons who, in the exercise of discretionary power, are motivated by a purpose other than the purpose for which the power was given may be in breach of duty.

An extra dimension is added to the application of the proper purposes rule when entities articulate purposes - the default proper purpose for the exercise of a power where the purpose of the power is not stated is the interests of the entity ${ }^{37}$ and an entity's purpose shapes its interests. This is all the more important in the charitable sphere due to the importance of purpose in maintaining charitable status and registration. It is also in some ways more straightforward in the sense that the charity's purposes are more easily identified.

\section{Duty of Care}

The duty in regulation 45.25(2)(a) of the ACNC Regulation is the duty of care and diligence. The duties in regulations $45.25(2)(\mathrm{f})$ and $(\mathrm{g})$ of the $A C N C$ Regulation - duties to ensure the entity's financial affairs are managed in a responsible manner and to not allow the registered entity to operate while insolvent - are subsets of this broader duty. ${ }^{38}$ This duty is impacted by purpose in the following ways. First, responsible persons of charitable entities must act with care, skill and diligence in seeking to further the charity's purpose. Responsible persons are not, however, in breach of this duty if they fail to achieve the entity's purpose(s). The standard imposed under this duty (in the context of the Governance Standards and in other contexts) takes into account the type of entity. ${ }^{39}$ In the case of charitable entities purposes are integral to the type of entity and therefore important in this matrix.

Emanating from the duty of care are the charity's compliance requirements the duty of care requires responsible persons to monitor and ensure compliance by the charity with regulatory requirements. This is linked with purpose in the sense that complying with applicable laws and requirements maintains charitable status and also fosters public support, thus allowing the charity to pursue, and hopefully achieve, that purpose. Organising compliance around purpose shows that there is

35 Lewski (2018) 362 ALR 286, 304 [71] (Kiefel CJ, Bell, Gageler, Keane and Edelman JJ).

36 See, eg, Howard Smith Ltd v Ampol Petroleum Ltd [1974] AC 821 ('Howard Smith Ltd'); Whitehouse v Carlton Hotel Pty Ltd (1987) 162 CLR 285; Eclairs Group Ltd v JKX Oil \& Gas Plc (2016) 3 All ER 641.

37 See Harlowe's Nominees Pty Ltd v Woodside (Lake Entrance) Oil Co No Liability (1968) 121 CLR 483, 493 (Barwick CJ, McTiernan and Kitto JJ), quoted in Howard Smith Ltd [1974] AC 821, 836 (Lords Wilberforce, Diplock, Simon of Glaisdale, Cross of Chelsea and Kilbrandon); Advance Bank Australia $v$ FAI Insurances Australia Ltd (1987) 9 NSWLR 464, 486-8 (Kirby P).

38 See, eg, Australian Securities and Investments Commission v Healey (2011) 196 FCR 291 ('Healey').

39 See, eg, Australian Securities and Investments Commission v Maxwell (2006) 59 ACSR 373, 397 [100] (Brereton J); Healey (2011) 196 FCR 291, 330 [165] (Middleton J). 
a reason for such compliance, thus serving a motivational role, as argued in Part III above.

\section{Avoiding Unauthorised Conflicts and Profits}

The Governance Standards in ACNC Regulation 45.25(2)(c)-(e) stem from the duties to avoid unauthorised conflicts of interest and profits from position. They require responsible persons to avoid misuse of position and information from position and to disclose conflicts. One aspect of these duties is to protect purpose by dissuading responsible persons from being tempted away from pursuing the charity's purposes. As articulated by the Australian Charities and Not-for-profits Commission, a charity's purpose is an essential consideration in managing conflicts of interests. ${ }^{40}$

\section{Summary}

In summary, charities need to carefully consider and specify their purpose. This purpose is a requirement for obtaining and maintaining charitable registration and associated benefits. It is also the guiding principle in the governance of such entities. As shown in the second half of this article, this distinctive model has transformative potential in relation to non-charitable entities.

\section{FOR-PROFIT CORPORATIONS}

This Part critically analyses whether purpose can play a more defining role in the governance of for-profit corporations. ${ }^{41}$ It is argued below that such corporations do not have to be wholly for profit. In addition, it is now beyond doubt that directors of such companies must have regard to the interests of stakeholders in acting in the interests of such companies. ${ }^{42}$

A key difference between charitable and non-charitable entities is the fact that charities are required to articulate (and stay true to) their purpose. Moreover, purpose is more likely to have more weight in the decision-making of responsible persons of charitable entities due to the financial incentives in staying true to charitable purpose and therefore maintaining charitable and tax status.

$40 \quad$ See 'Managing Conflicts of Interest' (n 27) 7.

41 A 'for-profit company' is generally understood to be a company that can distribute profits to shareholders. Note that some companies (such as no liability companies and charitable companies that wish to omit the word 'Limited' from their name) are required to specify purpose: see, eg, Corporations Act 2001 (Cth) ss 112(2), 150 ('Corporations Act').

42 See, eg, Australian Securities and Investments Commission v Cassimatis [No 8] (2016) 336 ALR 209, 301-2 [482]-[483] (Edelman J) ('Cassimatis') (upheld on appeal in Cassimatis v Australian Securities and Investments Commission (2020) 376 ALR 261); Banking Royal Commission Report (n 2) 401-2, 406; Corporations and Markets Advisory Committee, Parliament of Australia, The Social Responsibility of Corporations (Report, December 2006); Parliamentary Joint Committee on Corporations and Financial Services, Parliament of Australia, Corporate Responsibility: Managing Risk and Creating Value (Report, June 2006); Rosemary Teele Langford, 'Social Licence to Operate and Directors' Duties: Is There A Need for Change?' (2019) 37(3) Company and Securities Law Journal 200 ('Social Licence to Operate'). 


\section{A Current Role of Purpose}

A company's purpose does not currently play a clear role in the governance and regulation of for-profit companies in Australia. This can be seen by the following. First, the doctrine of ultra vires was abolished. ${ }^{43}$ Previously, companies were required to state their purposes in their constitution. Transactions or courses of action engaged in by companies outside of these stated purposes could be void. As outlined by Ford and Austin, a company's capacity was limited to doing only what was necessary for the attainment of the purposes specified in the objects clause in the company's constitution. ${ }^{44}$ In practice, however, company objectives were drafted in a compendious way.

Section 124 of the Corporations Act 2001 (Cth) ('Corporations Act') now provides that a company has the legal capacity and powers of an individual. Section 125(2) provides that company constitutions may set out companies' objects but that an act of the company is not invalid merely because it is contrary to or beyond any objects in the company's constitution. Companies are therefore no longer required to specify their objects and the objects of a company do not impose any legal limits on what a company can do, although they may be relevant in actions against directors for breach of duty or in oppression actions. ${ }^{45}$

Secondly, case law on the key duties to act in good faith in the interests of the company and for proper purposes demonstrates that corporate purposes do not play a big role. Case law on the duty to act in good faith in the interests of the company generally involves issues concerning creditors, group companies and conflicted directors. ${ }^{46}$ Case law on the duty to act for proper purposes (which has diminished due to the introduction of the Takeovers Panel) is more concerned with the boundaries of what directors cannot do. ${ }^{47}$

Thirdly, although larger for-profit companies do state their corporate objectives in the directors' report (required under section 299A(1) of the Corporations Act) ${ }^{48}$ very few articulate their purposes in the constitution. An

43 Companies and Securities Legislation (Miscellaneous Amendments) Act 1985 (Cth) s 47. The term 'ultra vires' here refers to ultra vires in the narrow sense (rather than ultra vires in the wide sense): see $A N Z$ Executors and Trustees Co Ltdv Qintex Australia Ltd (recs \& mgrs apptd) [1991] 2 Qd R 360, 370 (McPherson J) ('Qintex'); Darvall v North Sydney Brick and Tile Co Ltd (1988) 14 ACLR 474, 483 (Bryson J).

44 See HAJ Ford and RP Austin, Ford's Principles of Corporations Law (Butterworths, $6^{\text {th }}$ ed, 1992) 94 [504]. See also Ashbury Railway Carriage and Iron Co v Riche (1875) LR 7 HL 653. Ford and Austin comment that even a unanimous vote by the members purporting to authorise or ratify the relevant transaction or course of action could not remedy the defect.

45 See further below Part V(B).

46 For cases, see below Part V(D)(1). See also RP Austin and Ian M Ramsay, LexisNexis Ford, Austin \& Ramsay's Principles of Corporations Law (online at 20 June 2020) [8.070]-[8.160].

47 For detail, see ibid [8.200]-[8.240].

48 For critical analysis, see Reegan Grayson Morison and Ian Ramsay, 'An Analysis of Companies' Business Objectives' (2014) 32(6) Company and Securities Law Journal 438. Morison and Ramsay conducted research into the business objectives of companies and categorised the relevant stakeholder interests, as stated in the directors' report (required under section 299A(1) of the Corporations Act), that are taken into account. See also Ian Ramsay and Belinda Sandonato, 'An Analysis of the Business 
analysis of a random sample of 261 listed company constitutions demonstrates that only four companies specify their purpose in the constitution. ${ }^{49}$ The significance of articulating purpose in the constitution is examined in Part V(B) below.

On a theoretical level, however, the governance model that applies in the corporate sphere could be reconceptualised as purpose-based in the sense that the key (or default) purpose of for-profit companies is commonly seen as the generation of profits for shareholders. Some commentators see the interests of a for-profit company as the achievement of its purposes..$^{50}$

In the same way as purpose operates in the context of charitable entities, commitment to purpose can have a motivating and connecting role. According to the Ethics Centre, purpose is a core component of a company's ethical framework. ${ }^{51}$ Purpose-based governance also represents a new perspective through which decision-making can be approached in requiring conscious consideration of the company's purposes.

\section{B Potential Role}

Adoption of a purpose-based model in the corporate sphere could arguably bring benefits such as those articulated in Part III above. ${ }^{52}$ The last two decades have seen the rise of entities dedicated wholly or partly to social or public benefit purposes and also demand for the facilitation of a suitable corporate form for such entities. In addition, due to the increasing need for directors of for-profit companies to consider and even protect the interests of stakeholders,${ }^{53}$ boundaries between for-profit and not-for-profit companies are breaking down and convergence is occurring. Impact investing is also increasing, as are the stewardship obligations

Objectives of the Largest Listed Companies in Australia, the United Kingdom and the United States' (2018) 36(1) Company and Securities Law Journal 98.

49 In 2018 the constitutions of approximately 300 ASX listed entities from three categories of entities based on market capitalisation were obtained. The first category was the largest ASX listed entities and the constitutions of just over 100 entities in this category were obtained. The second category was approximately 100 entities selected at random from middle-sized capitalisation entities (those with a market capitalisation between $\$ 637$ million and $\$ 3.4$ billion). The third category was approximately 100 entities selected at random from small-sized capitalisation entities (those with a market capitalisation between $\$ 100$ million to $\$ 627$ million). The constitutions were obtained from the websites of the entities. Some constitutions were obtained from ASX announcements. Listed entities that are trusts or managed funds were excluded, as were companies which are incorporated under a foreign law. This left 261 constitutions of listed companies for analysis - 85 constitutions of the top 100 companies, 87 constitutions of middle-sized capitalisation companies and 89 constitutions of small-sized capitalisation companies. The constitutions were then searched for terms such as 'purpose', 'object' and 'mission'.

50 See, eg, Asaf Raz, 'A Purpose-Based Theory of Corporate Law' (Manuscript, University of Pennsylvania Law School, 19 June 2019) 8. See also Andrew Keay, Directors' Duties (LexisNexis, $3^{\text {rd }}$ ed, 2016) 153 [6.76].

51 Longstaff and Whitaker (n 1) 15.

52 For detailed analysis of the meaning of company purpose, see David Kershaw and Edmund Schuster, 'The Purposive Transformation of Company Law' (Law, Society and Economy Working Paper No 4/2019, Law Department, London School of Economics and Political Science, 31 March 2019).

See above $n 42$. 
expected of institutional investors. ${ }^{54}$ It has been shown that 'companies with a declared purpose, adhered to by their leadership teams and well understood by their stakeholders, perform better on key metrics over time than their less purposeful peers'. ${ }^{55}$ At the same time, generation of profit incentivises investment in companies and plays an important function given the economic importance of superannuation.

The potential for purposes to play more of a role in the corporate sphere can be seen in case law on duties of directors of corporate trustees. Present case law, albeit limited, sees the duties of directors of the corporate trustee as owed to the company (rather than to the beneficiaries or purposes of the trust) but sees these duties as being impacted and shaped by the duties owed by the company as trustee. For example the duty of care owed by directors of corporate trustees takes into account the nature of the company as a truste $e^{56}$ and the duty to act in good faith in the interests of the company requires directors to have regard to the interests of the beneficiaries because a breach of trust impacts on the company's interests. ${ }^{57}$

Essentially this means that the purposes of the company - to act as a trustee and therefore in the interests of the beneficiaries or charitable purposes of the trust - have direct and practical relevance in the application of the duties of the directors of the company. Just as the purpose of a charitable entity impacts on the core duties of its responsible persons, so the purpose of a corporate trustee - to act in the interests of beneficiaries or for charitable purposes - impacts on the duties of directors of the corporate trustee.

Articulation of purpose and purpose-based governance could play a practical role in determining to what extent directors of corporations can consider and promote stakeholder interests in the proper discharge of their duties. ${ }^{58}$ At present, stakeholder interests are relevant in the application of the duty to act in good faith in the interests of the company and the duty of care, although the extent of this relevance is fiercely contested. ${ }^{59}$ However, although stakeholder interests need to be considered by directors in considering the company's interests in complying with these duties, promotion of stakeholder interests requires a nexus with corporate benefit.

54 For appraisal, see Beate Sjåfjell and Mark B Taylor, 'A Clash of Norms: Shareholder Primacy vs Sustainable Corporate Purpose' (2018) 13(3) International and Comparative Corporate Law Journal 40, 58.

55 Big Innovation Centre, The Purposeful Company (Policy Report, February 2017) 6. See also Longstaff and Whitaker (n 1) 15.

56 See, eg, Trilogy Funds Management Ltd v Sullivan [No 2] (2015) 331 ALR 185, 231 [209] (Wigney J).

57 See, eg, Australian Annuities Pty Ltd (in liq) v Rowley Super Fund Pty Ltd (2015) 318 ALR 302, 350 [228] (Garde AJA).

58 For in-depth outline and appraisal of shareholder and stakeholder models, see Andrew Keay, 'Ascertaining the Corporate Objective: An Entity Maximisation and Sustainability Model' (2008) 71(5) Modern Law Review 663, 667-8. See also Justice James Edelman, 'The Future of the Australian Business Corporation: A Legal Perspective' (Conference Paper, Supreme Court of New South Wales Annual Corporate and Commercial Law Conference, 29 October 2019); Andrew Lumsden and Saul Fridman, 'Corporate Social Responsibility: The Case for a Self-Regulatory Model' (2007) 25(3) Company and Securities Law Journal 147; Paul Redmond, 'Directors' Duties and Corporate Social Responsiveness' (2012) 35(1) University of New South Wales Law Journal 31. 
Giving purpose more of a role in the corporate sphere would solve some of the issues surrounding the extent to which companies can consider and promote stakeholder interests. It would provide scope for companies to pursue nonfinancial impact-driven outcomes and social returns, if such objectives were adopted by shareholders. For example, directors of a company whose constitution included a purpose of 'benefit to all stakeholders, including shareholders, customers and clients, business partners and advisers, employees and the community ${ }^{60}$ or 'to foster the growth of [the company] for the benefit of all stakeholders ${ }^{\prime 61}$ would have more leeway and mandate to consider and promote stakeholder interests than directors of a company whose purposes were 'to maximise long term shareholder value through responsibly and sustainably investing in mining and related assets ${ }^{, 62}$ or 'to deliver long-term total shareholder returns, taking proper account of employees, customers, and others with whom we do business as well as with the communities and environments in which the company operates'.63

If purposes such as these were inserted into company constitutions, a determination of the company's interests for the purposes of the application of the duties to act in good faith in the interests of the company and the duty of care could, and would, be influenced by these purposes. Although such statements of purpose are high level and would not therefore dictate or determine the outcome of decisions, they would influence or determine the extent to which directors could consider and promote stakeholder interests. Greater weight would be accorded to such interests in companies with purposes in their constitution like the first two outlined above than in companies with purposes such as the latter two. Due to sections 124 and 125 of the Corporations Act, specification of company purposes would not affect the validity of corporate actions.

For purpose to play a more significant role in such conduct or in determination of the balance between shareholder and stakeholder interests, a company's purposes would arguably need to be enshrined in the company's constitution. This allows investors to choose whether to invest. Although, as argued below, companies are not legally required to have the pursuit of profit as their purpose

'The AMP Limited Board and management have a set of values that recognise the group's responsibilities to all its stakeholders, including shareholders, customers and clients, business partners and advisers, employees and the community': see AMP Ltd, Corporate Governance Statement (2013) 1, quoted in Morison and Ramsay (n 48) 445.

61 'At Sydney Airport, our vision is to deliver a world-class airport experience and foster the growth of Sydney Airport for the benefit of Sydney, [New South Wales] and Australia': see Sydney Airport, Vision and Values (2014), quoted in Morison and Ramsay (n 48) 446.

62 'Rio Tinto's overriding business objective is to maximise long term shareholder value through responsibly and sustainably investing in mining and related assets. Rio Tinto therefore recognises the importance of effective communication with shareholders and the general investment community': see Rio Tinto Ltd, Corporate Governance Standards (February 2007) 10, quoted in Morison and Ramsay (n 48) 444.

63 'ANZ aims to deliver superior long-term total shareholder returns, taking proper account of employees, customers, and others with whom we do business as well as with the communities and environments in which ANZ operates': see ANZ Bank Ltd, ANZ Board Charter (October 2013) [1.1], quoted in Morison and Ramsay (n 48) 444. 
and companies' interests are not equated solely with those of shareholders, a fundamental tenet of the Australian company law regime is that shareholders have the final word on a number of matters. In particular, shareholders have the power to remove directors ${ }^{64}$ and their approval is required for major changes and transactions. ${ }^{65}$

Enshrining purpose in the constitution also provides certainty where different investors have different expectations of the company. The expectations of traditional investors may, for example, diverge from those of impact investors. In addition, departure from stated purposes in a constitution or from 'legitimate expectations' may ground an oppression action or justify winding up on the just and equitable ground. ${ }^{66}$ A company's constitution could also specify the relative weight of different purposes where the company adopts multiple purposes. ${ }^{67}$ It is, however, notable that changing the constitution is difficult in practical terms in many cases due to the requirement of a special resolution. ${ }^{68}$

Adopting such objects in a company constitution also counters one of the risks of a broader stakeholder model, namely board accountability. ${ }^{69}$ Under the purposebased governance model articulated in this article, directors remain accountable to the company (and therefore, ultimately, to shareholders) - the beneficiary of directors' duties is not altered. Purpose-based governance does not in this sense presuppose or necessitate a stakeholder model. Rather, shareholders articulate and approve a company's objectives via the company's constitution. Clear and specific articulation of such purposes enhances board accountability and deals with the problems associated with the compendious specification of objectives historically in response to the ultra vires doctrine. ${ }^{70}$

A second potential disadvantage of purpose-based governance is that it could be seen to lessen the need for companies that do not adopt broader purposes in their constitution to act in a socially responsible way. This concern, however,

64 Corporations Act ss $203 \mathrm{C}$ and 203D.

65 See, eg, ibid ss 136 (changing the constitution), 157 (changing the company's name), 162 (changing the company's type), 256C (reducing capital), 257D (share buybacks), 260B (financial assistance), 208 (related party transactions).

66 See, eg, ibid s 461(1)(k); Re Tivoli Freeholds Ltd [1972] VR 445, 469 (Menhennitt J); O'Neill v Phillips [1999] 1 WLR 1092, 1102 (Lord Hoffman); Fexuto v Bosnajak Holdings Pty Ltd (2001) 37 ACSR 672. Note also Corporations Act s 140(1) as to the effect of a company's constitution - for detail, see Austin and Ramsay (n 46) [6.030].

67 In the absence of such predetermination, English law provides authority for the view that directors should balance the purposes of the entity and shareholder returns in the exercise of their discretion: see, eg, Stimpson v Southern Private Landlords' Association [2009] EWHC 2072 (Ch) [26] (Pelling J).

68 Corporations Act s 136.

69 For commentary on problems with board accountability under a stakeholder model, see The Social Responsibility of Corporations (n 42) 98-9 [3.8.2], 112 [3.12]; Senate Standing Committee on Legal and Constitutional Affairs, Parliament of Australia, Company Directors' Duties: Report on the Social and Fiduciary Duties and Obligations of Company Directors (Report, November 1989) 96-7 [6.45]-[6.47], 98 [6.51]; Redmond (n 58) 335.

70 There are interesting questions surrounding whether other stakeholders should have standing (as advocated by a stakeholder model of corporate law). Such expansion of standing is not necessary for purpose-based governance but is a question that merits exploration - for detailed appraisal, see Dana Brakman Reiser and Steven A Dean, Social Enterprise Law: Trust, Public Benefit and Capital Markets (Oxford University Press, 2017) 35-47. 
underscores the need for constant attention to the laws and regulations that govern companies and that define the boundaries within which companies operate. Purpose alone cannot be the driver of corporate responsibility. Such regulations and laws also set limits on the types of purposes that companies can legitimately adopt.

There has been concern that directors of companies that adopt purposes are vulnerable to actions for breach of duty if the company does not achieve the specified purposes. However, as explained in Part V(D)(1) below, this is not the way in which directors' duties operate. Careful framing of the company's purposes is also important in this respect.

\section{Proposals}

There are proposals to give purpose more of a role in the corporate sphere. In light of perceived failures of companies' roles in society (such as the rise of inequality of income and wealth, environmental degradation and increased mistrust in business), Mayer and the British Academy propound a radical reconceptualisation of business, encompassing changes to ownership, stewardship and regulation. ${ }^{71}$ In their view companies should be required to articulate their purpose - the purpose of business is not to produce profits but to produce profitable solutions for problems of people and planet. Directors' fiduciary responsibilities should not be centred on promoting shareholder interests but rather on promoting the corporate purpose. ${ }^{72}$ Likewise ownership should not be about control of the assets of companies but ownership of the company's purpose. This reconceptualisation of business and the regulation of business would require a paradigm shift involving legal reform.

Redefining corporate purpose could also play a role in moving to a stakeholder-oriented model of corporate law and therefore of directors' duties. Sjåfjell and Taylor advocate replacing the social norm of shareholder primacy with a legal norm of value creation, by redefining the purpose of companies as a matter of company law as 'creating sustainable value within the planetary boundaries while respecting the interests of its investors and other involved parties'.73 According to Sjåfjell, the board's duty is to ensure life-cycle based creation of sustainable value by adopting and regularly revising a long-term business plan for the company, based on a life-cycle assessment of the company's main areas of business. $^{74}$

These models require significant legal and regulatory changes and would effect a radical transformation of company law - the British Academy proposes mandatory specification of company purpose ${ }^{75}$ as part of a wider transformation

71 See above $\mathrm{n} 3$.

72 Mayer (n 3) 66.

73 Sjåfjell and Taylor (n 54) 62, citing Beate Sjåfjell, 'Bridge over Troubled Water: Corporate Law Reform for Life-Cycle Based Governance and Reporting’ (Research Paper 2016-23, Faculty of Law, University of Oslo, 2016).

74 Sjåfjell (n 73) 12; Sjåfjell and Taylor (n 54) 62-3.

75 Reforming Business for the $21^{\text {st }}$ Century (n 3) 22, 25. 
of corporate law and Sjåfjell and Taylor suggest mandating the types of purposes companies should be permitted to adopt. ${ }^{76}$ This article's aim is more modest in demonstrating the ability of companies to adopt purposes without the need for legal or regulatory reform.

A less radical role for purpose is envisaged by Fink, who sees purpose as the animating and guiding force of governance as well as of a company's existence and generation of profits, as the glue that connects a company's internal and external stakeholders. Fink states:

[E]very company needs a framework to navigate this difficult landscape, and ... it must begin with a clear embodiment of your company's purpose in your business model and corporate strategy. Purpose is not a mere tagline or marketing campaign; it is a company's fundamental reason for being - what it does every day to create value for its shareholders ... Purpose unifies management, employees, and communities. It drives ethical behaviour and creates an essential check on actions that go against the best interests of stakeholders. Purpose guides culture, provides a framework for consistent decision-making, and, ultimately, helps sustain long-term financial returns for the shareholders of your company. ${ }^{77}$

The most effective way of giving purpose more of a role in the for-profit sphere would therefore be to require (or invite) companies to articulate their purpose in the constitution. At the same time it is very important that continued attention be paid to regulation imposing minimum standards in relation to issues such as occupational health and safety, bribery, corruption, human rights, modern slavery and environmental obligations. ${ }^{78}$ As mentioned above, there is a clear role for the law to play in setting boundaries around permissible corporate behaviour. ${ }^{79}$

\section{Permissibility under Australian Law}

A question arises as to whether purpose can have this effect without law reform in light of the perception that shareholder primacy is mandated by law. Do forprofit companies need to be formed for the purpose of shareholder profit and will directors be in breach of duty if they give more weight to stakeholder interests or pursue social benefit purposes instead of, or in addition to, shareholder returns? Another question concerns whether directors of such companies may be liable for breach of duty if they do not achieve the company's purposes.

\section{Directors' Duties}

In some jurisdictions legislation enables special-purpose companies companies that have the achievement of a purpose as one of their objects. An example is the CIC regime in the UK. ${ }^{80}$ Section 172(2) of the Companies Act 2006 (UK) also facilitates the incorporation of such companies. It provides:

77 Larry Fink, 'Larry Fink's 2019 Letter to CEOs: Purpose \& Profit', BlackRock (Web Page, 2018)

$<$ https://www.blackrock.com/americas-offshore/2019-larry-fink-ceo-letter>.

78 See also Mayer (n 3) 67.

79 See also Cassimatis (2016) 336 ALR 209, 301 [482] (Edelman J).

80 Community interest companies were introduced in the UK in 2005 under the Companies (Audit, Investigations and Community Enterprises) Act 2004 (UK). Other examples are the different types of US public benefit corporations - for an outline and appraisal, see Dana Brakman Reiser and Steven A Dean, 
Where and to the extent that the purposes of the company consist of or include purposes other than the benefit of its members, subsection (1) has effect as if the reference to promoting the success of the company for the benefit of its members were to achieving those purposes.

This builds on section 172(1), which codifies the core duty to act in good faith in the interests of the company to require directors to act in the way they consider, 'in good faith, would be most likely to promote the success of the company for the benefit of its members as a whole', and in so doing have regard to a number of factors. $^{81}$

The Australian corporations legislation does not specifically enable specialpurpose corporations or recognise the role of purpose in the governance or regulation of companies. Corporations with purposes in addition to, or other than, shareholder returns are, however, arguably permissible despite the widespread perception that directors are required by law to prioritise shareholder returns. This is because section 181 of the Corporations Act requires directors to act in good faith in the interests of the company - there is no explicit requirement that a company be formed solely to generate profit for members and the duty is not owed to members. This is also the case at general law. ${ }^{82}$ The fundamental duty of directors is the duty to act in good faith in the interests of the company - where a company adopts purposes its interests are its purposes.

Section 181 also requires all directors to consider the company's interests, ${ }^{83}$ and to have regard to creditors' interests (as the company approaches insolvency) and to the interests of the particular company they direct (where the company is

\footnotetext{
'The Social Enterprise Life Cycle' in Benjamin Means and Joseph W Yockey (eds), The Cambridge Handbook of Social Enterprise Law (Cambridge University Press, 2018) 223; Lyman Johnson, 'Managerial Duties in Social Enterprise: The Public Benefit Corporation' in Benjamin Means and Joseph W Yockey (eds), The Cambridge Handbook of Social Enterprise Law (Cambridge University Press, 2018) 341. For recent proposals in relation to Australia and New Zealand, see B Lab Australia and New Zealand, 'Social Impact Investing Discussion Paper' (Submission, 27 February 2017) Attachment C $<$ https://reasury.gov.au/sites/default/files/2019-03/c2017-183167-B-Lab.pdf>; Jane Horan et al, The Impact Initiative, Structuring for Impact: Evolving Legal Structures for Business in New Zealand (Report, 2019).
}

81 There are, amongst other matters,

(a) the likely consequences of any decision in the long term; (b) the interests of the company's employees; (c) the need to foster the company's business relationships with suppliers, customers and others; (d) the impact of the company's operations on the community and the environment; (e) the desirability of the company maintaining a reputation for high standards of business conduct; and (f) the need to act fairly as between members of the company.

Companies Act 2006 (UK) s 172(1).

82 See below Part V(D)(2). Directors' general law duties are owed to the company (rather than to shareholders directly). The beneficiary of directors' statutory duties is not specified, with the courts emphasising the fact that the statutory duties protect a number of stakeholders: see, eg, Forge $v$ Australian Securities and Investments Commission (2004) 213 ALR 574, 654 [381] (McColl JA); Angas Law Services Pty Ltd (in liq) v Carabelas (2005) 226 CLR 507, 523 [32] (Gleeson CJ and Heydon J).

83 See also Re Gresham Life Assurance Society; Ex parte Penney (1872) LR 8 Ch App 446; Provident International Corporation v International Leasing Corp Ltd [1969] 1 NSWR 424, 437 (Helsham J); Walker v Wimborne (1976) 137 CLR 1, 6-7 (Mason J). 
part of a group) ${ }^{84}$ It also requires directors to avoid conflicts of interest (and duty) and profits from position (including conflicts involving third party interests and profits to third parties in the absence of attendant corporate benefit). ${ }^{85}$ There is no reason why these requirements should not apply to directors of companies that adopt purposes other than shareholder profit. The same is true in relation to the duty of care in section 180, the duties to avoid improper use of position and information from position in sections 182 and 183 and duties to disclose material personal interests in sections 191 and 195. There is therefore no legal impediment arising from Australian law on directors' duties to the adoption of purposes.

A concern has been raised as to whether directors are open to litigation for breach of duty if a company's purpose is not achieved in practice. This is not the case. As mentioned in Part IV(A) above, the duty to act in good faith in the interests of the company is not an absolute duty to achieve profits or purpose but rather requires directors to exercise their discretion in good faith in the furtherance of these goals. The same is true in relation to the duty of care - the duty does not require achievement of the company's purposes. Directors should make sure that they have considered the company's purposes and have applied care and diligence in furthering these purposes. ${ }^{86}$

\section{What are the Company's Interests?}

The perception that the interests of the company, for the purposes of the fundamental duty to act in good faith in the interests of the company (at general law and under section 181), are equated with those of shareholders stems from Greenhalgh v Arderne Cinemas Ltd, in which Evershed MR stated that

the phrase, 'the company as a whole', does not (at any rate in such a case as the present) mean the company as a commercial entity, distinct from the corporators: it means the corporators as a general body. That is to say, you may take the case of an individual hypothetical member and ask whether what is proposed is, in the honest opinion of those who voted in its favour, for that person's benefit. ${ }^{87}$

Although this case equates the company's interests with those of shareholders, it does not equate shareholders' interests with shareholder returns. It has been assumed that shareholder interests mean shareholder returns but this assumption

84 See, eg, Walker v Wimborne (1976) 137 CLR 1, 6-7 (Mason J); Qintex [1991] 2 Qd R 360, 374 (McPherson J); Equiticorp Finance Ltd (in liq) v Bank of New Zealand (1993) 32 NSWLR 50, 98, 100 (Kirby P), 148 (Clarke and Cripps JJA); Maronis Holdings Ltd v Nippon Credit Australia Pty Ltd (2001) 38 ACSR 404, 478 [300] (Bryson J); Bell Group Ltd v Westpac Banking Corporation [No 9] (2008) 39 WAR 1, 663 [6064], 668 [6088]-[6089] (Owen J) ('Bell Group [No 9]'); Westpac Banking Corporation v Bell Group Ltd (in liq) [No 3] (2012) 44 WAR 1, 169 [920], 178 [993], 182-3 [1011] (Lee AJA), 348 [1969], 363 [2031] (Drummond AJA).

85 See, eg, Chew v The Queen (1991) 4 WAR 21, 49 (Malcolm CJ); Adler v Australian Securities and Investments Commission (2003) 46 ACSR 504, 618 [539] (Giles JA); Bell Group [No 9] (2008) 39 WAR 1, 561 [4520] (Owen J); Fitzsimmons v R (1997) 23 ACSR 355, 363-4 (Parker J).

86 Although section 1324 of the Corporations Act provides for expanded standing, it is predicated on breach of the Corporations Act. As demonstrated, non-achievement of a company's purposes does not necessarily mean that directors have breached their statutory duties.

87 [1951] Ch 286, 291. For discussion, see Jean J du Plessis, 'Directors' Duty to Act in the Best Interests of the Corporation: "Hard Cases Make Bad Law"' (2019) 34(1) Australian Journal of Corporate Law 3; Edelman (n 58). 
does not necessarily follow. Moreover, even when the company's interests are properly equated with the interests of shareholders, shareholders can arguably choose to authorise the pursuit of purposes other than profit. As mentioned above, the focus of directors' duties under Australian law is the company and it is recognised that directors need to consider, and at times protect and promote, stakeholder interests in complying with their duties.

In addition, corporations were not originally formed as a vehicle for shareholder profit. The original use of the corporate form was by municipal and religious bodies. ${ }^{88}$ Corporations sole were used in relation to property left to the church, so as to distinguish between the natural person occupying the particular position (and therefore managing the land) in their official capacity and the same person in their private capacity, thus allowing property to pass to successive holders of the position. ${ }^{89}$ Corporations aggregate were used for groups that needed a legal existence that would survive the individuals composing them at any particular time, such as boroughs and colleges. ${ }^{90}$ The corporate form was also used for the purposes of obtaining a trading monopoly (generally in another jurisdiction). ${ }^{91}$

That companies can be incorporated for purposes other than profit was recognised by Milton Friedman, who is generally blamed for corporate law's focus on shareholder primacy:

In a free-enterprise, private-property system, a corporate executive is an employee of the owners of the business. He has direct responsibility to his employers. That responsibility is to conduct the business in accordance with their desires, which generally will be to make as much money as possible while conforming to the basic rules of the society, both those embodied in the law and those embodied in ethical custom. Of course, in some cases his employers may have a different objective. A group of persons might establish a corporation for an eleemosynary purpose - for example, a hospital or a school. The manager of such a corporation will not have money profit as his objective but the rendering of certain services. ${ }^{92}$

Given the current uncertainty that persists around this issue, the introduction of a provision like section 172(2) of the Companies Act 2006 (UK) may serve to signal the permissibility of incorporation for purposes other than profit and provide reassurance to directors. Adoption of purposes by for-profit companies is, however, permissible under Australian law without such reform.

88 See Rob McQueen, A Social History of Company Law: Great Britain and the Australian Colonies 18541920 (Ashgate, 2009) 1. See also Armand Budington DuBois, The English Business Company After the Bubble Act 1720-1800 (Octagon Books, 1971) 1.

89 Justice TF Bathurst, 'The Historical Development of Corporations Law' (2013) 37(3) Australian Bar Review 217, 218.

90 Ibid 218-19. See also Ron Harris, Industrializing English Law Entrepreneurship and Business Organization, 1720-1844 (Cambridge University Press, 2000) 39-42.

91 McQueen (n 88) 35.

92 Milton Friedman, 'The Social Responsibility of Business is to Increase its Profits' (13 September 1970) The New York Times Magazine. 


\section{CONCLUSION}

The application of a purpose-based governance model to a range of entities has conceivable advantages in terms of its prospective application regardless of an entity's form, its possible new ways of approaching and solving internal and external governance challenges and its potential to organise and motivate governance in a more effective way.

The article focused first on charitable entities. Such entities are required to specify their purpose and also to adhere to that purpose in order to obtain and maintain charitable registration and associated advantages. Governance in the charities sphere is naturally grounded on purpose given this core importance of purpose. It was shown that a charity's purpose is central to the core governance duties of responsible persons, namely the duties to act in good faith in the charity's best interests and for proper purposes, the duty of care and duties to avoid unauthorised conflicts and profits. A purpose-based governance model has the potential to recentre and refocus governance of charitable entities.

The clear role of purpose in the charitable sphere serves as a model for the potential operation of purpose in the for-profit sphere. It was shown that, although purpose does not currently play a central role in the governance and regulation of for-profit companies, there is definite potential for purpose to play a defining role. The first step is clear articulation of a company's purpose(s) in the constitution. Giving purpose more of a role in the corporate sphere has transformative potential, particularly in relation to the vexed question of stakeholder interests. Careful critical analysis clarifies that Australian law allows companies to adopt purposes in addition to, or other than, shareholder profit in the constitution, paving the way for governance centred on purpose. Purpose-based governance does not, however, fundamentally alter the current accountability structure and does not expose directors to liability if they do not achieve the company's specified purposes.

Although not necessarily the panacea for all governance conundrums, purposebased governance has much to offer. At the very least it is a new lens through which to approach persistent and intractable governance issues. More fundamentally, purpose has significant potential as an overarching governance model. It may, in addition, serve to increase trust in institutions. 


\section{University Library}

\section{- M M I N E R VA A gateway to Melbourne's research publications}

Minerva Access is the Institutional Repository of The University of Melbourne

Author/s:

Langford, R

Title:

Purpose-based Governance: A New Paradigm

Date:

2020-09

Citation:

Langford, R. (2020). Purpose-based Governance: A New Paradigm. University of New South Wales Law Journal, 43 (3), pp.954-976. https://doi.org/10.53637/tdws1787.

Persistent Link:

http://hdl.handle.net/11343/243031 